\title{
REPRESENTATION MODES OF DWARF ANIMAL-KEEPER
}

\author{
By \\ Ola El-Aboudy \\ Lecturer of Ancient Egyptian Art and Architecture at the Faculty of Archaeology, Cairo University
}

\begin{abstract}
[Ar]

دراسة فنية لتصوير القزم كحارس للحيوانات الاليفة

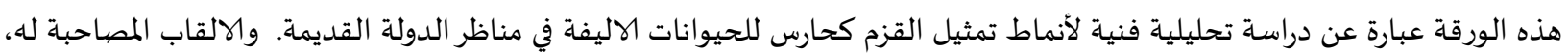

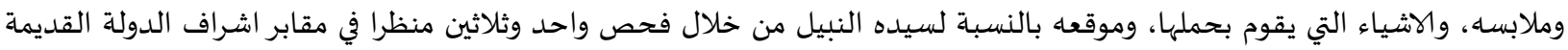

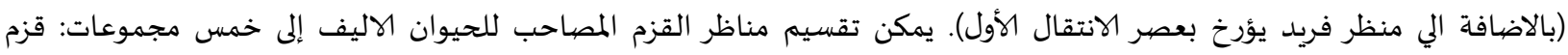

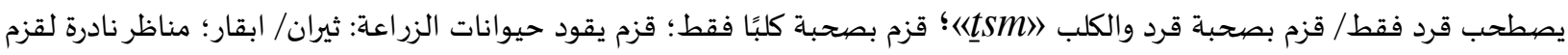
يقود نمر / غزال. ثم تحليل تأثير وظيفة القزم هذه على قرد المكانة الاجتماعية لسيده النبيل.
\end{abstract}

[EN] This paper is an artistic analytical study of the dwarf animal keeper's representation modes in Old kingdom scenes, their titles, clothes, portables, and positions to their master. This was achieved throughout the profound examination of thirty-one scenes in Old kingdom tombs. The dwarf accompanying a domestic animal could be divided into five groups: Dwarf with a monkey only; with a monkey together with a «tsm» dog; Dwarf attending a dog only; a dwarf leading agriculture animals and another rare scene of a dwarf leading a leopard/ gazelle. Furthermore, I shall analyze the influence of this dwarf's function on the social position of his noble.

KEYwORDS: Dwarf, Animal keeper's dwarf titles, Dwarf clothes, Dwarf portables, Dwarf positions, a monkey, a «tsm»dog, Oxen, Cow, Leopard, Gazelle. 


\section{INTRODUCTION}

It is considered one of my professional life's great fortunes that my master's and Ph.D. degrees were under Professor Ali Radwan's supervision. In the spirit of his generosity to his former students, this study is dedicated to him.

This article aims to be an artistic analytical study of the representation modes related to a dwarf as an animal keeper in Old kingdom scenes and their different portrayals and interpretations. The paper would also discuss the effect of this dwarf role in ancient Egyptian society as a kind of luxury served to show the deceased's wealth and social status based on examining a group of scenes in Old kingdom tombs.

Dwarfism is considered the commonly depicted human physical disorder in daily activity; dwarfs achieved high-ranking positions ${ }^{1}$ reflect their acceptance and full respect in Egyptian society ${ }^{2}$.

There are two main categories of short stature: a disproportionate type, where restricted growth affects the limbs, the trunk, or both in varying degrees, and a proportionate type, where the whole body is involved and remains small ${ }^{3}$. The hieroglyphic words for dwarfs and pygmies were: $d n g, d 3 n g, d_{3} g$, accompanies with a

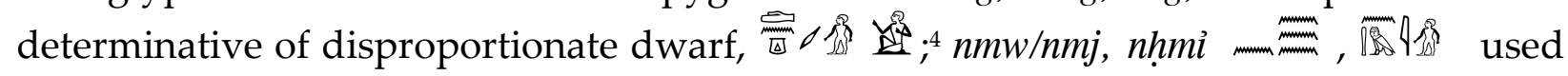
from the Middle Kingdom, mostly in magical and religious texts ${ }^{5} h w^{r}$ is used from the Old Kingdom, usually designates someone short ${ }^{6}$. The term $i w h w$ would more plausibly refer to a person's physical aspect rather than a function?

In the Old Kingdom, dwarfs appear following their masters in the procession ${ }^{8}$. They served in carrying objects ${ }^{9}$ of their master - his staff, sandals, head-rest and fly-whisk. They represented in scenes of manufacturing jewelry ${ }^{10}$. They worked as dancers ${ }^{11}$,

${ }^{1}$ The Dwarf Seneb. CHERPION 1984: 34-54, PLS.1-11. Periankhw: HAWAS 2004. Khnumhotep. CODY 2004: 374, FIG.25, 2.

${ }^{2}$ LICHTHEIM 1976: 160.

${ }^{3}$ DASEN 1988: 32: 2, 255. EL- AGUIZY: 1987: 53-60.

${ }^{4}$ ERMAN \& GrapoW (eds.): Wb. Vol.5: 470: 5-7. SetHe 1960: §1189a-1189b. Letter sent from Pepi II to Harkhuf: SETHE 1903:128:15, 129:17, 130:5. DASEN 1993: 25-6.

5 «nmw» in the tomb of Khety: NEWBERRY 1893: 32, PL.16. The dwarf gods Bes and Ptah are also called «nTw»: DASEN 1993: 30.

${ }^{6}$ DASEN 1993: 259.

${ }^{7}$ FISCHER 2002: 37-38.

${ }^{8}$ Tomb of Nikauhor. Quibell 1909: PL. 42.2. The scene of Meryteti. KANAWATI \& ABDER-RAZIQ 2004: PL.7b, FIG.47. Tomb of Nesuwt-nofer. JUNKER 1938: 35, ABB.27.

9 Tomb of Kawab. SIMPSON 1978: PL.72. Tomb of Niankhkhnum and Khnumhotep. HARPUR 2010: 413. Tomb of Khnumenti: (Carrying box / basket) BROVARSKI 2001: 120-122, FIG.86, PL.90a. Tomb of Whemka. KAYSER 1964: 36-37. Tomb of Wpmnfrt: JUNKER 1938: 53. Tomb of Ni-Maat-Re': HASSAN 1936: FIG.240. Servant Statue of dwarf with a sack: ROTH 2002: 110. (Carrying a mirror). DAVIES 1902: PL.17. Tomb of Khnumenti (carrying box). BROVARSKI 2001: FIG.94. Tomb of Mereri (carrying box). DAvies 1984: 11, PLs.5, 8. Tomb of Khentika (giving a box to his master. JAMES 1953: PL. 31. Statue of dwarf carrying a kohl pot: BOTHMER 1949: 9-11.

${ }^{10}$ Sndmib-Mhj. JUnKer 1938: 53. Tomb of Nefer and Kahay. MOUSSA \& AltenMÜlLeR 1971: 25, PL.9. HaRpur 2015: Pls.112, 307. Tomb of Ankhmahor. BADAWY 1978: PL.32, PL.35. Tomb of Ptahhotep. Harpur 2008: 23-25; Davies 1902: Pl.14. Tomb of Inti. Petrie 1898: Pl.13; Kanawati \& McFarlan 1993: PL.28. 
whereas dwarfs took part in bird-catching ${ }^{12}$ or acting as boat pilots. Female dwarfs also were followers ${ }^{13}$ and served as nurses for young children ${ }^{14}$.

Taking care of pets was the most common work performed by dwarfs. It seems possible that it is connected with the wealth, prestige and luxury that a dwarf created for the deceased itself, as the author will discuss this according to their positions to the tomb owner, their titles and clothes.

Male dwarfs appear with domestic animals: baboons, monkeys, dogs and cows. One could notice that some dwarfs have the main job of looking after animals, but others were employed on the side. They always represented close to the tomb owner, as higher-ranking attendants. In some cases, they were identified by their titles or their names ${ }^{15}$. They were preferable to their masters as the dwarf dog-keeper Ipy buried in his master's rock-tomb.

Title of animal-keeper in the Old Kingdom can hardly found; as for the dwarf, one could find a glimpse in the tomb of Shepsi-Pu-Min/Kheni and Nyankhnefertem, or perhaps for $j w h w$ ? Which occurs in the tomb of Ty and dwarf Seneb titles ${ }^{16}$. In some cases, other titles accompany the dwarf keeper, as in the tomb of Seshemnefer-tjetti and Neferirtenef. In only one case, the tomb of Nefer the dwarf took an epithet. In three cases, his name is kindly written as shown in [TAB 1].

\begin{tabular}{|c|c|}
\hline Tomb & Dwarf name/title \\
\hline Nikauisesi & 'YIIIIIII A 'Irỉ (name) \\
\hline Ty & 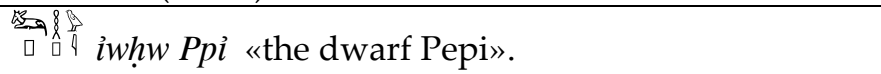 \\
\hline Shepsi-Pu-Min/Kheni & $8 \rrbracket_{H b b \text { (name) }}$ \\
\hline Seshemnefer-tjetti & 18. $N$ Nfr-wdnt (name) \\
\hline Nefer, called Idu & Pof $m r r i$ «the beloved one». \\
\hline Neferirtenef & $\overline{\prod_{\text {住 }}}$ sms follower (Title) \\
\hline Shepsi-Pu-Min/Kheni & $\begin{array}{l}\text { ○ष罗 } 8 d_{d j r j(?)-} g f H b b \text { «The keeper of the monkey } \\
H b b \text { ». }\end{array}$ \\
\hline Nyankhnefertem & $\square$ In $n b . s n$ «their master» (their: dog- monkey) \\
\hline Seshemnefer.-tjetti & $\Delta_{i m y-r \text { sšr Nfr-wdnt } \text { «overseer of the linen, } N f r-w d n t » .}$ \\
\hline
\end{tabular}

[TAB 1] @ Done by the researcher

11 «dng jb3w ntrr» "dwarf of the god's dances". SETHE 1903: 128:15; SETHE 1903: 129:17-130:5; SETHE 1960: 517, §1189a-1189b. Dancing at the mortuary ceremonies of the Apis and Mnevis bulls. BAINS 1992: 24157. The depictions of dwarfs working themselves as musicians are very rare: a unique scene in the tomb of Kaaper. FISCHER 1959: FIG.8.

${ }^{12}$ Tomb of Hesi. Kanawati 1999: Pl.29.

${ }^{13}$ Tomb of Queen Mersyankh III (G 7530). REISNER 1942: 251. Wife of Mereruka. WRESZINSKI 1936: PL.11.

${ }^{14}$ KOZMA 2010: 309.

15 THOMPSON 1991: 92-93.

${ }^{16}$ DAWSEN 1938: 187-188; DASEN 1993: 31; FISCHER 1980: coll. 77-78. 
In ten scenes, the dwarfs wear pointed triangular kilt, indicate their higher status, while in eight scenes, they consume traditional kilt. The dwarf is naked in four scenes; unfortunately, in six scenes, clothes are not well preserved. A kilt with a sash appears once in the tomb of Zau. Additionally, a tied belt around the waist with hanging ends appeared once in the tomb of Inti/Deshasha. The dwarf in the tomb of Inti / Abusir wears a collar [TAB 2].

Some dwarfs carry batons to control their pet; this appears in six scenes [with extra fragmentary scene in tomb of $I \underline{i} i-s n^{17}$, a basket for monkey food appeared once in the tomb of Ankhmahor. Sometimes he holds his master sandals while minding a pet as in Shepsi-Pu-Min / Kheni and Niankhnesut, indicating the affection and devotion to his master; once he holds Linen bag and long staff. Most scenes show dwarf accompany the noble pet in position of: standing next to/in front of/behind or even under his master. He appeared moderately under the palanquin accompanying his master possession. But diminutive under his lord chair. As shown in [TAB 2]. In these scenes, the dwarf illustrates the pet's idea as a valuable property of his master. While the dwarf emphasized that he is the protector of his master's interests. Thirty-one scenes in Old kingdom tombs show a dwarf accompanying a domestic animal; eleven scenes show the dwarf accompany a monkey only. Eight scenes show a dwarf leading a monkey together with a «tssm» dog, while seven scenes show a dwarf accompanying a dog. Five more scenes could be added, to a dwarf leading a cow and another rear scene of a dwarf leading a leopard.

According to the available scenes, V. d'Abbadie's opinion, which confessed that usually, dwarves were monkeys' guardians during the Old Kingdom, must be questioned.

${ }^{17}$ Giza, $5^{\text {th }}$ dynasty. WeEKS 1994: 266,269, FIG.122; Sourdive 1984: PL.12, FIG.2. 
Festschrift of Professor Ali Radwan [1941-2020]

\begin{tabular}{|c|c|c|c|c|c|c|c|c|c|c|}
\hline Tomb & $\begin{array}{l}\text { Pointed } \\
\text { kilt }\end{array}$ & $\begin{array}{l}\text { Regular } \\
\text { kilt }\end{array}$ & Naked & $\begin{array}{l}\text { Clothes } \\
\text { not } \\
\text { preserved } \\
\end{array}$ & $\begin{array}{l}\text { Standing } \\
\text { next to }\end{array}$ & $\begin{array}{l}\text { Standing } \\
\text { in front of }\end{array}$ & $\begin{array}{l}\text { Standing } \\
\text { behind master }\end{array}$ & $\begin{array}{l}\text { Standing } \\
\text { Under } \\
\text { palanquin } \\
\end{array}$ & $\begin{array}{l}\text { Standing } \\
\text { Under chair }\end{array}$ & $\begin{array}{l}\text { Portable } \\
\text { stuff }\end{array}$ \\
\hline $\begin{array}{l}\text { Ankhmahor } \\
\text { Saqqara/ } 6^{\text {th }} \text { dyn. }\end{array}$ & & $\sqrt{ }$ & & & & & $\sqrt{ }$ & & & Basket \\
\hline $\begin{array}{l}\text { Ankh-ma-ra } \\
\text { Giza/ } 5^{\text {th }} \text { dyn. }\end{array}$ & & & & $\sqrt{ }$ & & & & & & \\
\hline $\begin{array}{l}\text { Hesi } \\
\text { Saqqara/ } 6^{\text {th }} \text { dyn. }\end{array}$ & $\sqrt{ }$ & & & & & & $\sqrt{ }$ & & & \\
\hline $\begin{array}{l}\text { Inti/ Abusir/ } \\
6^{\text {th }} \text { dyn. }\end{array}$ & $\begin{array}{l}\sqrt{ } \\
\text { With } \\
\text { collar } \\
\end{array}$ & & & & & & & & $\mathrm{v}$ & \\
\hline $\begin{array}{l}\text { Inti/Deshasha/ } \\
5^{\text {th }} \text { dyn. fig. } 28 .\end{array}$ & & $\sqrt{ }$ & & $\sqrt{ }$ & & & & & & \\
\hline $\begin{array}{l}\text { Inti/Deshasha/ } \\
5^{\text {th }} \text { dyn. fig. } 29 .\end{array}$ & & $\sqrt{ }$ & & Rear/ belt & & & & & & \\
\hline $\begin{array}{l}\text { Ipi Beni } \\
\text { Hasan/Old } \\
\text { Kingdom } \\
\text { necropolis }\end{array}$ & $\sqrt{ }$ & & & & & & & & $v$ & Baton \\
\hline $\begin{array}{l}\text { Ireru Giza/ } 5^{\text {th }}-6^{\text {th }} \\
\text { dyn. }\end{array}$ & & $\sqrt{ }$ & & & & $\sqrt{ }$ & & & & \\
\hline $\begin{array}{l}\text { 'Iti } i-s n \quad \text { Giza/ } 5^{\text {th }} \\
\text { dyn. }\end{array}$ & & & & $\begin{array}{l}\text { Damaged } \\
\text { kilt }\end{array}$ & & & & & & \\
\hline $\begin{array}{l}\text { Kaemnofret Giza/ } \\
5^{\text {th }} \text { dyn. }\end{array}$ & $\sqrt{ }$ & & & & & & $\sqrt{ }$ & & & Baton \\
\hline $\begin{array}{l}\text { Kagemni Saqqara/ } \\
6^{\text {th }} \text { dyn. }\end{array}$ & $\sqrt{ }$ & & & & & & & $\sqrt{ }$ & & \\
\hline $\begin{array}{l}\text { Kai-khent El- } \\
\text { Hammamiya/ } 5^{\text {th }} \\
\text { dyn. }\end{array}$ & & $\sqrt{ }$ & & & $\sqrt{ }$ & & & & & \\
\hline $\begin{array}{l}\text { Kanefer Giza/ } 5^{\text {th }} \\
\text { dyn. }\end{array}$ & & & $\sqrt{ }$ & & & & $\sqrt{ }$ & & & \\
\hline $\begin{array}{l}\text { Mereruka } \\
\text { Saqqara/ } 6^{\text {th }} \text { dyn. }\end{array}$ & & & $\sqrt{ }$ & & & & & $\sqrt{ }$ & & Baton \\
\hline $\begin{array}{l}\text { Mrw Naga ed- } \\
\text { Der/ } 1^{\text {st }} \\
\text { intermediate } \\
\text { period }\end{array}$ & & $\sqrt{ }$ & & & $\sqrt{ }$ & & & & & \\
\hline $\begin{array}{l}\text { Nefer/ Idu Giza/ } \\
6^{\text {th }} \text { dyn. }\end{array}$ & $\sqrt{ }$ & & & & & & & & $\mathrm{v}$ & \\
\hline $\begin{array}{l}\text { Neferirtenef } \\
\text { Saqqara/ } 5^{\text {th }} \text { dyn. }\end{array}$ & $\sqrt{ }$ & & & & & & & $\begin{array}{l}\sqrt{ } \text { his } \\
\text { master }\end{array}$ & & \\
\hline $\begin{array}{l}\text { Nefermaat } \\
\text { Maidum/ } 4^{\text {th }} \text { dyn. }\end{array}$ & & & $v$ & & - & - & - & - & - & \\
\hline $\begin{array}{l}\text { Niankhnesut } \\
\text { Saqqara/ } 6^{\text {th }} \text { dyn. } \\
\text { fig.17. }\end{array}$ & $\mathrm{V}$ & & & & - & - & - & - & - & Sandals \\
\hline $\begin{array}{l}\text { Niankhnesut } \\
\text { Saqqara } 6^{\text {th }} \text { dyn. } \\
\text { fig. } 31 \text {. }\end{array}$ & & $\mathrm{v}$ & & & - & - & - & - & - & $\begin{array}{l}\text { Linen } \\
\text { bag }\end{array}$ \\
\hline $\begin{array}{l}\text { Nihetepptah/ } \\
\text { Peni Giza } 5^{\text {th }} \text { dyn. }\end{array}$ & & & & $v$ & & & & $v$ & & \\
\hline Nikauisesi & & $\mathrm{v}$ & & & & & $\mathrm{v}$ & & & \\
\hline $\begin{array}{l}\text { Nikauisesi Saqqar } \\
\text { a/ } 6^{\text {th }} \text { dyn. }\end{array}$ & $v$ & & & & & & & $\mathrm{v}$ & & \\
\hline $\begin{array}{l}\text { Nyankhnefertem } \\
\text { Saqqara/ } 6^{\text {th }} \text { dyn. }\end{array}$ & & & & $\mathrm{v}$ & & & $\mathrm{v}$ & & & \\
\hline Pepiankh/kem & & & & $\mathrm{v}$ & & & & & $\mathrm{v}$ & \\
\hline
\end{tabular}




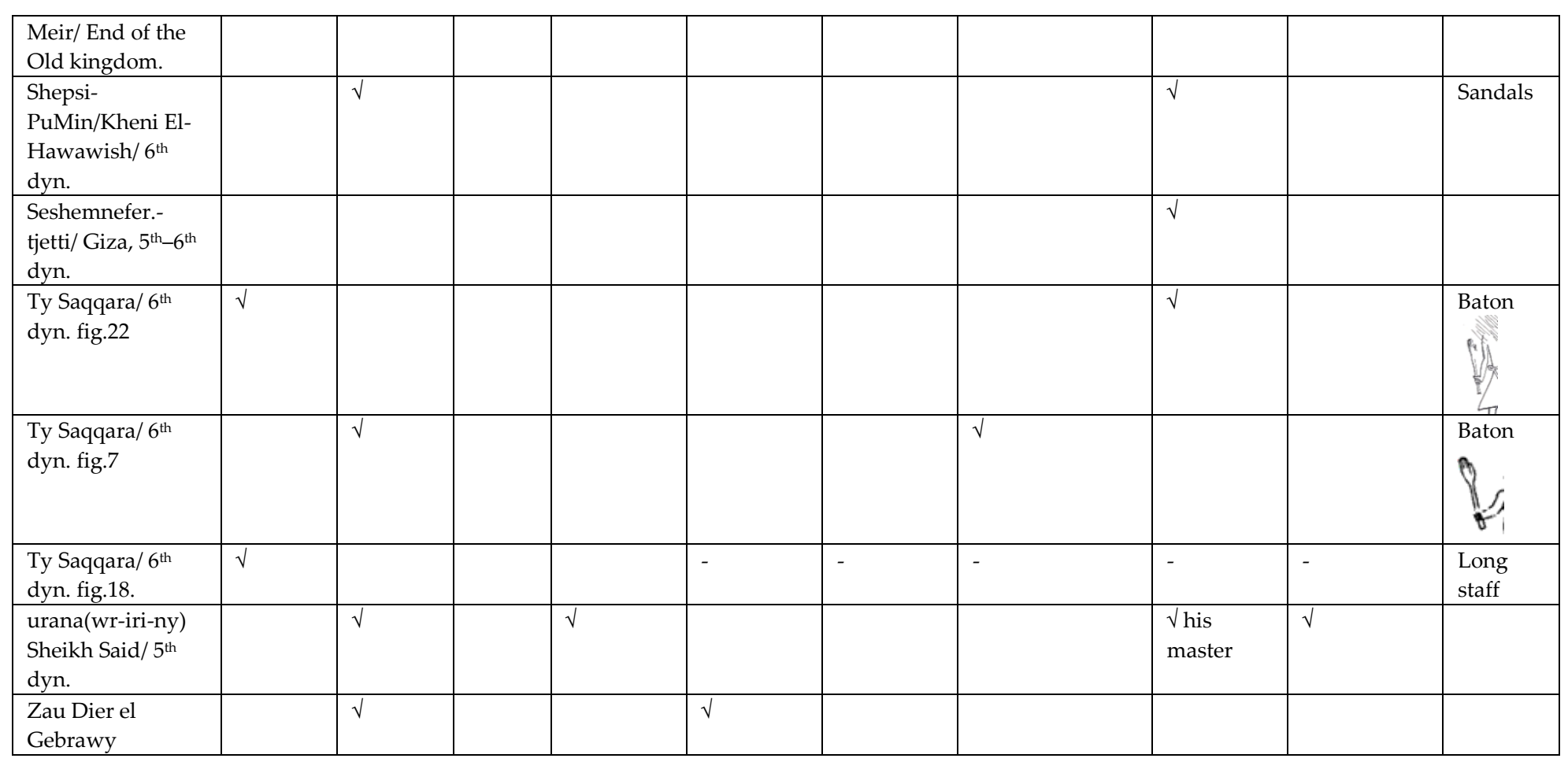

[TAB 2] @ Done by the researcher

\section{DWARF WITH MONKEY}

Most Monkeys ${ }^{18}$, which accompany dwarfs, are slender Cercopithecus ${ }^{19}$. They are often shown collared and leashed to curb the unpredictable nature of monkeys. In seven scenes, these restraints fastened around the monkey's neck; in the tomb of Kanefer only, a belt is shown around the abdomen together with a collar. The leashes are rope made ${ }^{20}$, always short to fit the dwarf arms' proportions; based on this, the monkeys did not have enough space to move far away from the dwarf. This property is perhaps what made V. d'Abbadie ${ }^{21}$ suggest that monkeys were much tamed and more obedient with the dwarf, analyst this by coming from the same home regions. The dwarf holds a short baton together with the leash while minding a monkey in two cases: the tomb of Ty [a short baton ends with hand shape ${ }^{22}$. Which is large if compared to the size of the dwarff ${ }^{23}$ and in the tomb of Kaemnofret. The monkey is free without any leach in Nikauisesi and Nefermaat's tomb. In two cases the world $g f$ which refers to its faction, was written (Kaemnofret: $\mathbb{A}_{0}^{\circ}$ gf.t female monkey, and Shepsi-Pu-

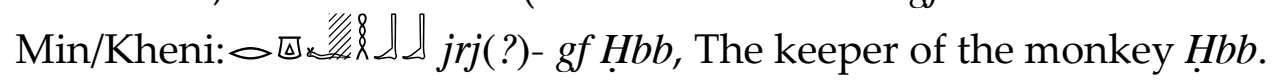

\footnotetext{
${ }^{18}$ Normal attendants occupied with monkeys: Tomb of Ppjj-enh (.w) / Hnjj-km. BLACKMAN 1953: PL.31. Guardsmen with baboons on a leash: Tomb of Niankhkhnum and Khnumhotep: MOUSSA \& AltenMÜLleR 1977: FIG.10. Tomb of Tepemankh II. YvONNE \& MARKOWITZ 2002: 405, FIG.126. Tomb of Sabwibbi; BORCHARDT 1937: 91-96, PL.21.

${ }_{19}$ DASEN 1993: 116.

${ }^{20}$ D'ABBADIE 1964: 152, 159.

${ }^{21}$ D'ABBADIE 1964: 171; Dasen follows his opinion. DASEN 1993:116.

${ }^{22}$ The same baton occurs with normal monkey keeper in the market scene from the tomb of Tepemankh II at Saqqara (Cairo CG 1556): YvONNE \& MARKOWITZ 1999: 405, FIG.126.

${ }^{23}$ SOURDIVE 1984: PL.10.
} 
The monkey stands upon his dwarf master head in three scenes: The tomb Kanefer $^{24}$ [FIGURE 1], the tomb of Nikauisesi ${ }^{25}$ [FIGURE 2] and the tomb of Nefer/Idu ${ }^{26}$ [FIGURE 3].

A monkey sits on dwarf shoulders in two scenes: The tomb of Ankhmahor ${ }^{27}$, (the dwarf hold a basket full of figs/eating monkey [FIGURE 4]) and in the tomb of Nikauisesi, ${ }^{28}$ (eating monkey/ three dogs walk freely with names as l $_{3 i}$, $B 3 k$, and Ad Id 3 [FIGURE 5]).

They follow their dwarf guardians on the ground in six scenes. Sometimes the dwarf is very little taller than the squatting monkey (urana/wr-iri-ny), or the one he holds by the leash (Ty).

The tomb of urana (wr-iri-ny) ${ }^{29}$ (eating squatting monkey [FIGURE 6]), the tomb of $\mathrm{Ty}^{30}$ (with a short baton [FIGURE 7]), the tomb of Kaemnofret ${ }^{31}$ (short baton/world gf.t [FIGURE 8]), the tomb of Shepsi-Pu-Min called Kheni ${ }^{32}$ (two monkeys ? / one climbs up his shoulders (remain only its tail) /carrying his master's sandals FIGURE 9), the tomb of Kai-khent ${ }^{33}$ [FIGURE 10]., and the tomb of Nefermaat (unproportioned naked dwarf ${ }^{34}$, large head, the lower leg is short and bowing ${ }^{35}$, one hand touches a monkey, and another monkey caches the other [FIGURE 11]).

\section{DWARF WITH Dogs}

Most dogs that accompany dwarfs are Egyptian Tesem-dogs; They were very common during the Old Kingdom ${ }^{36}$; accompany their owner in different positions ${ }^{37}$ mostly hunt scenes ${ }^{38}$. Nevertheless, dwarf never appears with dogs in hunt scenes.

Dogs often presented with a specific type of collar with a big loop under the neck, or sometimes lay on the back, defines them as domesticated. They are not always leashed,

${ }^{24}$ Giza 2150, early $5^{\text {th }}$ dynasty, eating? Monkey. ReISNER 1942: FIG.263; MANUELIAN \& SIMPSON 2009: 313, FIG.12.76; D' ABBADIE 1964: 159, FIG.23.

${ }^{25}$ Saqqara, early $6^{\text {th }}$ dynasty. KANAWATI \& ABDER-RAZIQ 2009: PL. 55.

${ }^{26}$ Giza, $6^{\text {th }}$ dynasty. JUNKER 1947: 82, ABB.35, TAf.14. D'ABBADIE 1964: 159, FIG.24.

${ }^{27}$ Saqqara, $6^{\text {th }}$ dynasty. CAPART 1907: PL.41; KLEBS 1915: 32f; BADAWY 1978: FIG. 33; KANAWATI 1997: PL.71; D'ABBADIE 1964: 159, Fig.22.

${ }^{28}$ Saqqara, $6^{\text {th }}$ dynasty. KANAWATI \& ABDER-RAZIQ 2009: PL. 48, FIG.55. This dwarf «Iri» may be the same as «Iriniptah», who appears on the west wall of chamber III in the same tomb.

${ }^{29}$ Sheikh Said, $5^{\text {th }}$ dynasty. DAVIES 1901: 12f, FIG.4; D'ABBADIE 1964: 159, FIG.25.

30 Saqqara, $6^{\text {th }}$ dynasty. WILD 1953: PL.126; D'ABBADIE 1964: 159, PL.12.

${ }^{31}$ Giza, late $5^{\text {th }}$ dynasty. BADAWY \& SIMPSON 1976: 15, PL.17b; SIMPSON 1992: ABB.7.

${ }^{32}$ El-Hawawish, $6^{\text {th }}$ dynasty. KANAWATI 1981: 26, FIG.21. He may hold the third monkey in his right hand.

${ }^{33}$ El-Hammamiya, early $5^{\text {th }}$ dynasty. El-KhOuli \& KanAwati 1990: 65, PL.67.

34 DAWSEN 1938: 187.

35 Maidum, $4^{\text {th }}$ dynasty: Petrie 1892: Pl.21,24; HARPUR 2001: 77-78, 81-87, FIGS.81-86, PLS.13-25; HARPUR 1987: FIG. 168.

${ }^{36}$ SCHULZ 2006: 317, 323; REISNER 1936: 96-99.

37 Tomb of Iymery. Weeks 1994: 44, FIG.36. Dogs under the palanquin without dwarf: Tomb of Shepseskafankh G6020. WEEKS 1994: 38, FIG.32.

${ }^{38}$ DAVIES 1900: PL.22; HARPUR 2008: 139-141. 
as shown in six tombs of Nikauisesi, Ankh-ma-ra, Neferirtenef, Nihetepptah, Ty and Mereruka. That may be due to its predictable movement, as mentioned in Any's Instruction: "The dog obeys the word, and walks behind its master» ${ }^{39}$.

As with the monkey, leashes are always short to fit the dwarf arms; based on this, dogs are always near their dwarf master. Some dogs were given personal names

$[\mathrm{TAB} 3]^{40}$.

\begin{tabular}{|c|c|}
\hline Tomb & Dogs \\
\hline Inti/Abusir & «Idm» \\
\hline Neferirtenef & «ikni» $f_{21}$ \\
\hline Niankhnesut & $\begin{array}{l}\text { 1)《lr(w)em-sšr» } \\
\text { 2) «ists.t» }\end{array}$ \\
\hline Nikauisesi & 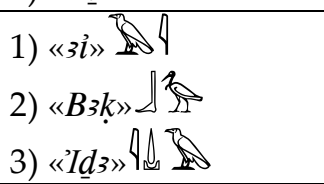 \\
\hline Nyankhnefertem & «ichil» $4 \rightleftharpoons 0$ \\
\hline urana (wr-iri-ny) & 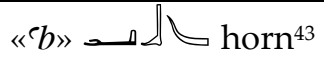 \\
\hline
\end{tabular}

[TAB 3] @ Done by the researcher

In seven scenes, dwarf appears with «tsm» dogs only. Three cases show squatting dogs: Inti ${ }^{44}$ (dog called 'Id $\underline{d}$ [FIGURE 11]), tomb of Ipi ${ }^{45}$ (with baton [FIGURE 13]) and tomb of Pepiankh-(kem)/Hni-(Kem) ${ }^{46}$ (dwarf thrusting an object/food? into dog's mouth [FIGURE 14]).

In four cases, the dogs follow their dwarf guardians: Rock-cut tomb of Ankh-mara $^{47}$ [FIGURE 15], the tomb of urana (wr-iri-ny) ${ }^{48}$ (The dwarf is looking back/dog's name «ab», FIGURE 16), the tomb of Niankhnesut ${ }^{49}$ (With dog names' «lr(w)-m-sšr», «ỉst.st», [FIGURE 17]), the tomb of Ty ${ }^{50}$ (with a long staff, [FIGURE 18]).

The dwarf stands in most of the scenes; he has the same height as a squatting dog in Pepiankh or appears a little taller in Ipi / Beni Hasan, while in urana, his head is shorter than the chin of a walking dog.

\footnotetext{
39 MU-CHOU POO 2005: 134; WENTE 1990: 35.

${ }^{40}$ This habit begins from the $1^{\text {st }}$ dynasty onwards. FISCHER 1961: 152-153; usually identical to humans. Fischer 1980: 78.

${ }^{41}$ JANSSEN 1958: №.7.

42 Means: flying/ volatile/ swift; KURASZKIEWICZ 2004: 79.

${ }^{43}$ JANSSEN 1958: №.16.

${ }_{44}$ Abusir/Archive of the Czech Institute of Egyptology, $6^{\text {th }}$ dynasty. BÁRTA 2006: 54, FIG.8; BÁRTA 2011: 186.

${ }^{45}$ Beni Hasan, Old Kingdom necropolis. SOURDIVE 1984: 34-36, PL.13.

${ }^{46}$ Meir, end of the Old kingdom. BLACKMAN \& APTED 1953: 27, PL.19.

${ }^{47}$ Giza: 7837, 5 ${ }^{\text {th }}$ dynasty. REISNER 1936: 98; REISNER 1942: 368.

${ }^{48}$ Sheikh Said, late $5^{\text {th }}$ dynasty. DAVIES 1901: PL.6.

${ }^{49}$ Saqqara, 6 $6^{\text {th }}$ dynasty, painted limestone. H. 57.5; W. 210 cm. MÜLLER 1964: 56f, (cat. A90) K 415A); DASEN 1993: 117, PL.24; D'ABBADIE 1964: 159, FIG.18.

${ }^{50}$ Saqqara, early $6^{\text {th }}$ dynasty. Wild 1953: PL.128.
} 


\section{DWARF WITH MONKEY AND DOG}

There is no change in the animal movement behavior when depicted together, and that differs from what V. d'Abbadie ${ }^{51}$ mentions that the monkeys seem to be very obedient when represented with the dogs. Commonly, the pets are led by a leash but sometimes move freely behind the dwarf.

Eight scenes show monkeys and dogs follow their dwarf master, five of them show the animals distributed in two sub-registers: Tomb of Neferirtenef ${ }^{52}$ (with title «šms» follower/ dog name «ikni» [FIGURE 19]), the tomb of $\mathrm{Hesi}^{{ }^{53}}$ [FIGURE 20], the tomb of Nyankhnefertem, known as Temi5 ${ }^{54}$ (with title «nb.sn» their master/dog named «ichi» / dwarf has broad-strong shoulders, FIGURE 21), the tomb of Nihetepptah / Peni ${ }^{55}$ [FIGURE 22], and the tomb of Seshemnefer-tjetti ${ }^{56}$ (with title-name «imy-r šsr Nfr-wdnt» overseer of the linen $N f r$-wdnt [FIGURE 21]).

Three scenes show the animals in one row; two scenes only in Mereruka and Kagemni show more than two animals accompany the dwarf. Tomb of Ty ${ }^{57}$ (with long baton suited to dwarf size as the leash ${ }^{58} /$ title «iwhw Ppi» the dwarf Ppi [FIGURE 22]), the tomb of Mereruka ${ }^{59}$ (two naked dwarfs/with three dogs/one monkey/short baton, [FIGURE 23]). The tomb of Kagemni ${ }^{60}$ (A dwarf with two leaches / three pets [FIGURE 24]).

\section{DWARF With Agriculture ANIMAlS}

It may seem strange that dwarves of small size were dedicated to lead animals more massive than their size; five scenes show dwarfs leading a 'young ox' or a cow in a procession of these animals, using a leash made usually from a rope. It is noticed that in four scenes, the dwarf holds the leach with his two hands: Tomb of Kai-khent ${ }^{61}$ (very large head turned back to look at the ox [FIGURE 26]), the tomb of Ireru: Giza 8698, $5^{\text {th }}$ $6^{\text {th }}$ dynasty [FIGURE 27]), the tomb of Inti ${ }^{62}$ (Practice sketches /a turned head / another short man helps with rope [FIGURE 28]), and another scene in the tomb of Inti63 (with

\footnotetext{
${ }^{51}$ D'ABBADIE 1964: 159.

${ }^{52}$ Saqqara D 55, late $5^{\text {th }}$ dynasty, now in Brussels, Musée d'Art et d'Histoire E.2465. WALLE 1978: PL.12; THOMPSON 1991: FIG.3; CHERPION 1989: 130.

53 Saqqara, early $6^{\text {th }}$ dynasty. KANAWATI \& ABDER-RAZIQ 1999: PLS.53-54; KANAWATI 2001: FIG. 88.

${ }^{54}$ Saqqara, $6^{\text {th }}$ dynasty. MYŚLIWIEC \& KURASZKIEWICZ 2010: 198-199, FIG.61, PL.71, 80.

${ }^{55}$ Giza 2430, late $5^{\text {th }}$ dynasty? ALtenMUELLER 1981: 16, FIG. 2.

${ }^{56}$ Giza, $5^{\text {th }} 6^{\text {th }}$ dynasty. JUNKER 1953: 249-250, ABB.100; D'ABBADIE 1964: 159, FIG.17; Dasen 1993: 114.

${ }^{57}$ Saqqara, early $6^{\text {th }}$ dynasty. STEINDROFF 1913: PL.15; WILD 1953: PL.15; DAUMAS 1939: PL.16; D'ABBADIE 1964: 159, FIG.13.

${ }_{58}$ SOURDIVE 1984: PL.9, FIG.1-2.

59 Saqqara, early $6^{\text {th }}$ dynasty. Duell 1938: PLS.157-158; D'ABBADIE 1964: 159, FIG.14; SouRdive 1984: PL.12, FIG.1.

${ }^{60}$ Saqqara, early $6^{\text {th }}$ dynasty. BISSING 1911: PL.22; KLEBS 1915: ABB.21; HARPUR 2006: 425, 278, 288-291; D'ABBADIE 1964: 159, FIG.16.

${ }^{61}$ El-Hammamiya, early $5^{\text {th }}$ dynasty. KHOULI \& KANAWATI 1990: 41, PLS.43, 45; THOMPSON 1991: FIG.5.

${ }^{62}$ Deshasha, $5^{\text {th }}$ dynasty. KANAWATI \& MCFARLANE 1993: 28, PL.32.

${ }^{63}$ Petrie 1898: PL.11. KANAWATI \& MCFARLANE 1993: 27, PLS.5, 30.
} 
a turned head/a belt around his waist (appeared only here) / another short man helped him [FIGURE 29]). In the two scenes of Inti's tomb, more than one short man is guiding the ox. In the last scene in tomb of Zau ${ }^{64}$ (FIGURE 30), a small man wears a kilt with a sash accompanied by a cow.

\section{IV.DWARF WITH UNIQUE ANIMALS}

A unique relief shows a dwarf leading a tamed leopard and a walking monkey by a leash for a walk in Tomb of Niankhnesut ${ }^{65}$, (with linen bag on his back, [FIGURE 31]). The dwarf pay no attention to the accompanying animals, perhaps the leopard was kept in captivity to be trained for hunting purposes. No comparable scene in the old Kingdom. In order to differentiate leopard from cheetahs ${ }^{66}$, it was represented by holds its head below the shoulders level, which makes it easy compared to the monkey that appeared in tomb of Mereruka and Ty. A Comparative scene of a dwarf leading a gazelle taller than him is in the tomb of Mrw / good name Iy Aw ${ }^{67}$ [FIGURE 32].

\section{Conclusions}

The dwarf animal keeper figures are mostly disproportionate type in very realistic appearance, with a large head, short limbs, and regularly very short hands. Only 11 cases are in disproportionate type. The artist was very competent in dealing with its hindering; arms are always slightly bent in the elbows and drawn aside from the body; however, holding leach or portables. Rarely stretched out or crossed on the chest. Their equipment is always small, short to fit their short hands. The leach is always short to fit their proportions. Most of the dwarfs dressed; some wear pointed kilts, indicating their higher status. However, their titles refer to their special rank to their master. Keeper dwarf depicted in high folk tombs complete their eliteness and prestige form. It seems that dwarfs with agriculture animals are less than those who mind their master pets; they did not hold any titles and never wear a pointed kilt; in one case, a belt was used. Furthermore, the dwarves well understand of the methods of dealing with and controlling all depicted pets.

\footnotetext{
${ }^{64}$ Dier el Gebrawy: DAviES 1902: 10, PL.9.

${ }^{65}$ Saqqara, 6 $6^{\text {th }}$ dynasty, painted limestone. H. 57.5; W. $210 \mathrm{~cm}$. MüLLER 1964: 56f, (cat. A90) K 415A); DASEN 1993: 117, PL.24. D'ABBADIE 1964: 159, FIG.18.

${ }^{66}$ EVANS 2010: 114-115.

${ }^{67}$ Naga ed-Der N3737. First Intermediate Period. PECK 1958: 113, PL.13.
} 


\section{BIBLIOGRAPHY}

D'ABBADIE, V.: «Les Singes Familiers L'Ancienne Égypte», Revue d'Égyptologie 16, 1964, 147-177.

AltenmülleR, H. \& MoussA, A.: The Tomb of Nefer and Ka-hay, Mainz am Rhein (Philipp von Zabern) 1971.

D'AbBadie, V. \& Moussa, A.: Das Grab des Nianchchnum und Chnumhotep, Mainz am Rhein (Philipp von Zabern) 1977.

: «Das Grab des Hetepniptah G 2430 auf dem Westeriedhof von Giza», SAK 9, 1981, 9-19.

BADAWY, A.: The Tombs of Iteti, Sekhemankhptah, and Kaemnofret at Giza, Berkeley, Los Angeles, London (University of California Press) 1976.

BADAWY, A.: The Tomb of Nyhetep-Ptah at Giza and The Tomb of Ankhma'ahor at Saqqara, Berkeley, Los Angeles, London (University of California Press) 1978.

BAINS, J.: «Merit by Proxy: The Biographies of the Dwarf Djeho and his Patron Tjaiharpta», JEA 78, 1992, 241-257.

BÁRTA, M.: Journey to the West, the World of the Old Kingdom Tombs in Ancient Egypt, Prague (Charles University, Faculty of Arts) 2011.

BÁRTA, M.: «The Sixth Dynasty Tombs in Abusir: Tomb Complex of the Vizier Qar and his family», in The Old Kingdom Art and Archaeology: Proceedings of the Conference held in Prague, May 31 - June 4, 2004, M. BARTA (ed.), 45- 62, Prague (Czech Institute of Egyptology) 2006.

BISSING, V.: Die Mastaba des Gem-Ni-Kai, Berlin (A. Glaue vormals A. Duncker) 1911.

BlaCKMAN, A.M.: The Rock Tombs of Meir, Part V, London (Egypt Exploration Fund) 1953.

BOTHMER, B.V.: «The Dwarf as Bearer», Bulletin of the Museum of Fine Arts 47/ 267, 1949, 9-11.

BrovarsKI, E.: The Senedjemib Complex, Part 1: The Mastabas of Senedjemib Inti (G 2370), Khnumenti (G 2374), and Senedjemib Mehi (G 2378), Boston (Museum of Fine Arts) 2001.

CAPART, J.: Une Rue de Tombeau a Saqqarah, vol 2, Bruxelles (Vromant \& C) 1907.

CHERPION, N.: «De Quand Date La Tombe Du Nani Seneb?», BIFAO 84, 1984, 35-54.

CHERPION, N.: Mastabas et Hypogées, Mastabas et Hypogées, d'Ancient Empire, Bruxelles (Connaissance de l’Égypte Ancienne) 1989.

CODY, M.E. (ed.): Egyptian Art, Selected Writings of Bernard V. Bothmer, Oxford (Oxford University Press) 2004.

DASEN, V.: «Dwarfism in Egypt and Classical antiquity: Iconography and Medical History», Medical History 32/3, 1988, 253-276.

: Dwarfs in Ancient Egypt and Greece, Oxford (Clarendon Press) 1993.

DAvies, N. de G.: The Mastaba of Ptahhetep and Akhethetep at Saqqareh, I, London (Egypt Exploration Fund) 1900.

Davies, N. de G.: Deir el Gebrawi, vol. I, London (Egypt Exploration Fund) 1902.

DAVIES, N. de G.: The Rock Tombs of Sheikh Said, London (Egypt Exploration Fund) 1901.

DAVIES, W. V.: Saqqara Tombs I: The Mastabas of Mereri and Wernu, London (Egypt Exploration Society) 1984.

DAWSEN, W.R.: «Pygmies and Dwarfs in Ancient Egypt», JEA 24/2, 1938, 185-189.

Duell, P.: The Mastaba of Mereruka, Part II, Chicago, Illinois (The University of Chicago Press) 1938.

EPRON L. \& DAumAS F.: Le Tombeau de Ti I, Le Caire (Impr. de l'Institut Français d'Archéologie Orientale) 1939.

ERMAN, A. \& GRAPOW, H. (eds.): Wörterbuch der Ägyptischen Sprache I-V, Leipzig (J. Hinrichs) 1926-1931 [= $W b$.$] .$

EL-AguizY, O: «Dwarfs and Pygmies in Ancient Egypt», ASAE 71, 1987, 53-60.

Evans, L.: Animal Behaviour in Egyptian Art, Oxford (Aris and Philipps Ltd.) 2010.

FISCHER, H.G.: «A Scribe of the Army in a Saqqara Mastaba of the Early Fifth Dynasty», JNES 18, 1959, 233-272.

FISCHER, H.G.: «A Supplement to Janssen's List of Dogs' Names», JEA 47, 1961, 152-153. 
FISCHER, H.G.: «Some Titles Associated with Dwarfs and Midgets» GM 187, 2002, 37-38.

JAMES, T.G.H. \& APTED, M.R.: The Mastaba of Khentika Called Ikhekhi, London (Egypt Exploration Fund) 1953.

JANSSEN, J.M.A.: «Über Hundenamen im Pharaonischen Ägypten», MDAIK 16, 1958, 179, 1958, 179-182.

JUnKER, H.: Giza III: Die Maștabas der Vorgeschrittenen V. Dynastie auf dem Westfriedhof, Leipzig (HölderPichler-Tempsky A. G.) 1938.

JUNKER, H.: Gîza V, Die Mastaba des Śnb (Seneb), Wien, Leipzig (Hölder-Pichler-Tempsky) 1941.

JUNKER, H.: Gîza VIII, Wien (Kommission bei Rudolf M. Rohrer) 1947.

HARPUR, Y.: Decoration in Egyptian Tombs of the Old Kingdom, London, New York (KPI limited) 1987.

HARPUR, Y.: The Tombs of Nefermaat and Rahotep at Maidum, Oxford (Oxford Expedition to Egypt) 2001.

HARPUR, Y.: The Chapel of Kagemni, Oxford (Oxford Expedition to Egypt) 2006.

HARPUR, Y.: The Chapel of Ptahhotep, Oxford (Oxford Expedition to Egypt) 2008.

HARPUR, Y.: The Chapel of Niankhkhnum and Khnumhotep, Oxford (Oxford Expedition to Egypt) 2010.

HARPuR, Y.: The Chapel of Nefer and Kahay, Oxford (Oxford Expedition to Egypt) 2015.

HASSAN, S.: Excavations at Giza II: 1930-1931, Cairo (Government Press) 1936.

HAWAS, Z.: «The Dancing Dwarf» The Ambassadors Online Magazine: The Forum for Culture and Civilization 7, 2004, accessed march 28, 2020. http://ambassadors.net./selected. study.htm.

KANAWATI, N.: The Rock Tombs of El-Hawawish: The Cemetery of Akhmim, vol. 2, Sydney (Macquarie Ancient History Association) 1981.

KanawATI, N. \& El-Khouli A.: The Old Kingdom Tombs of El Hammamiya, Sydney (The Australian Centre for Egyptology) 1990.

: Deshasha: The Tombs of Inti, Shedu and Others, Sydney (The Australian Centre for Egyptology) 1993.

: The Teti Cemetery at Saqqara. Volume II: The Tomb of Ankhmahor, Warminster (Aris \& Phillips). 1997.

: The Teti Cemetery at Saqqara, Volume V: The Tomb of Hesi, Warminster (Aris \& Phillips) 1999.

: The Teti Cemetery at Saqqara VI: The Tomb of Nikauisesi, Warminster (Aris \& Phillips) 2000.

: The Tomb and Beyond: Burial Customs of Egyptian officials, Warminster (Aris \& Phillips Ltd.)

2001. Phillips) 2004.

\& Abder-Raziq M.: Mereruka and his Family, Part 1: The Tomb of Meryteti, Oxford (Aris \&

KAYSER, H.: Die Mastaba des Uhemka: ein Grab in der Wüste Hannover, (Fackelträger-Verlag Schmidt-Küster $\mathrm{GmbH)} 1964$.

KLEBS, L., Die Reliefs des Alten Reiches, Heidelberg (Carl Winters Universitätsbuchhandlung) 1915.

Kozma, C.: "The Ancient Egyptian Dwarfs of the Walters Art Museum», American Journal of Medical Genetics 2010, 2556-2562. https://onlinelibrary.wiley.com/doi/pdf/10.1002/ajmg.a.33616.

KURASZKIEWICZ, K.: «Two Dogs Names from Saqqara», GM 202, 2004, 79-80.

LiChTHEIM, M.: Ancient Egyptian Literature, vol.2, the New Kingdom, Chicago (University of Chicago Press) 1979.

MANuelian, P.Der. \& SimPSON, W. K.: Giza Mastabas VIII: Mastabas of Nucleus Cemetery g 2100, Part I, Boston (Museum of Fine Arts) 2009.

Mu-CHOU, POO.: Enemies of Civilization, New York (State University of New York Press) 2005.

MÜLLER, H.W.: Ägyptische Kunstwerke: Kleinfunde und Glas in der Sammlung E. und M. Kofler-Truniger, Luzern, Berlin (Bruno Hessling) 1964.

MYŚLIWIEC, K. \& KurAsZKIEWICZ, K.: Saqqara Polish-Egyptian Archaeological Mission 4, The Funerary Complex of Nyankhnefertem, Varsovie (Editions Neriton) 2010.

Newberry, P.E.: Beni Hasan, Part 2, London (Kegan Paul, Trench, Trübner \& Co. Ltd.) 1893.

Petrie, W.: Medum, London (David Nutt) 1892.

PETRIE, W.: Deshasheh, London (The Egypt Exploration Fund) 1898. 
PECK, C.N.: Some Decorated Tombs of the First Intermediate Period at Naga ed-Dêr, Ann Arbor (UMI Dissertation Services) 1958.

QuiBELL, J.E.: Excavations at Saqqara (1907-1908), Le Caire (Service des Antiquités de l'Égypte) 1909.

REISNER, G.A.: A History of the Giza Necropolis, vol. 1, Cambridge (Harvard University Press) 1942.

REISNER, G.A.: «The Dog Which Was Honored by the King of Upper and Lower Egypt», Bulletin of the Museum of Fine Arts, 34/ 206, 1936, 96-99.

RоTH, A.M.: «The Meaning of Menial Labor: "Servant Statues" in Old Kingdom Serdabs», JARCE 39, 2002, 103-121.

SChulZ, R.: «Dog Missing His Master: Reflections on an Old Kingdom Tomb Relief in the Walters Art Museum, Baltimore», in The Old Kingdom Art and Archaeology: Proceedings of the Conference held in Prague, May 31 - June 4, 2004, M. BARTA (ed.), 315- 324, Prague (Czech Institute of Egyptology) 2006.

SETHE, K.: Die Altägyptischen Pyramidentexte, Darmstadt (Wissenschaftliche Buchgesellschaft; [puis] Hildesheim: G. Olms) 1960.

SETHE, K.: Urkunden des Alten Reichs, Band I und II., Leipzig (J.C. Hinrichs'sche Buchhandlung) 1903.

SIMPSON, W.K.: Giza Mastabas III, the Mastabas of Kawab, Khafkhufu I and II, Boston (Museum of Fine Arts) 1978.

SIMPSON, W.K.: The Offering Chapel of Kayemnofret in the Museum of Fine Arts, Boston (Department of Egyptian and Ancient Near Eastern Art, Museum of Fine Arts) 1992.

SOURDIVE, C.: La Main dans l'Égypte Pharaonique, Berne - Francfort (Peter Lang) 1984.

SteINDROFF, G.: Das Grab des Ti, Leipzi (J. C. Hinrichs'sche Buchhandlung) 1913.

THOMPSON, E.: «Dwarfs in the Old Kingdom in Egypt» BACE 2, 1991, 91-98.

WAlle, V. Der.: La Chapelle Funéraire de Neferirtenef, Brussels (Musées Royaux d'Art et d'Histoire) 1978.

WENTE, E.: Letters from Ancient Egypt, Atlanta (Scholar Press) 1990.

WeEKS, K.R.: Giza Mastabas V: Mastabas of Cemetery G 6000 Including G 6010 (Neferbauptah); G 6020 (Iymery); G 6030 (Ity); G 6040 (Shepseskafankh), Boston (Museum of Fine Arts) 1994.

WILD, H. Le Tombeau de Ti, II, Le Caire (Impr. de l'Institut Français d'Archéologie Orientale) 1953.

WRESZINSKI, W.: Atlas zür Altägyptischen Kulturgeschichte, Teil III, Leipzig (J. C. Hinrichs) 1936.

YVONNE, J. \& MARKOWITZ: Egypt in the Age of the Pyramids: Highlights from the Harvard University-Museum of Fine Arts, Boston (Mass.: MFA Publications) 2002. 


\section{FIGURES}

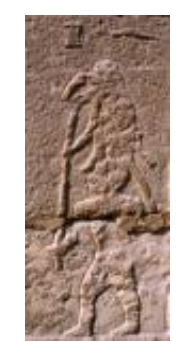

[FIGURE 1]:

Tomb of

Kanefer/giza/5 $5^{\text {th }}$ dyn.

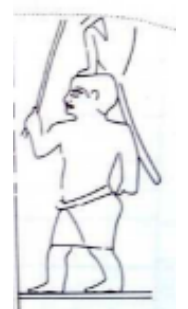

[FIGURE 2]:

Tomb of

Nikauisesi/

Saqqara/6 $6^{\text {th }}$ dyn.

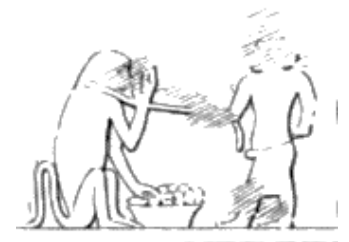

[FIGURE 6]:

Tomb urana (wr-iri-ny)/ Sheikh Said. $5^{\text {th }}$ dyn.

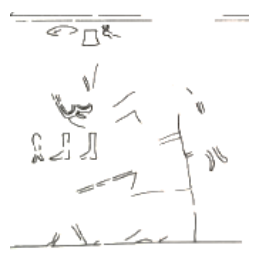

[FIGURE 9]:

Tomb of Shepsi-PuMin/Kheni/ El-Hawawish. $6^{\text {th }}$ dyn.

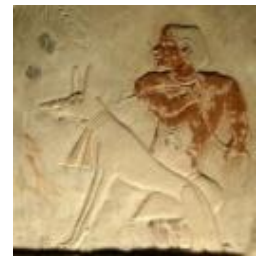

[FIGURE 12]:

Funerary chapel of Inti/ Abusir, Archive of the Czech Institute of Egyptology.

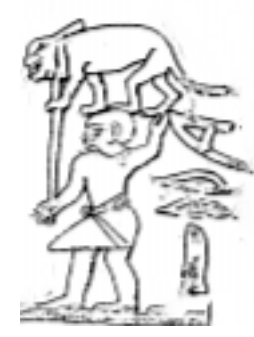

[FIGURE 3]:

Tomb of Nefer/Idu, Giza. $6^{\text {th }}$ dyn.

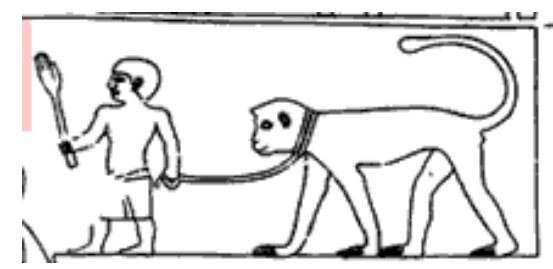

[FIGURE 7]:

Tomb Ty/ Saqqara. $6^{\text {th }}$ dyn.

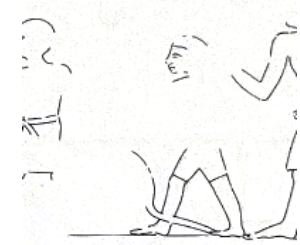

[FIGURE 10]:

Tomb of Kai-khent/ElHammamiya. $5^{\text {th }}$ dyn.

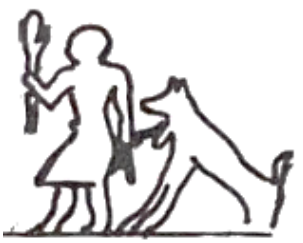

[FIGURE 13]:

Tomb of Ipi, Beni Hasan/ Old Kingdom.

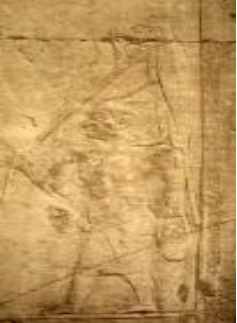

[FIGURE 4]:

Tomb of Ankhmahor/

Saqqara. $6^{\text {th }}$ dyn.
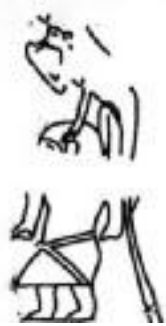

[FIGURE 5]:

Tomb of

Nikauisesi/ Saqqara. $6^{\text {th }}$ dyn.

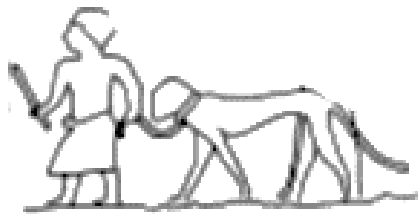

[FIGURE 8]:

Tomb of Kaemnofret/Giza. $5^{\text {th }}$ dyn.

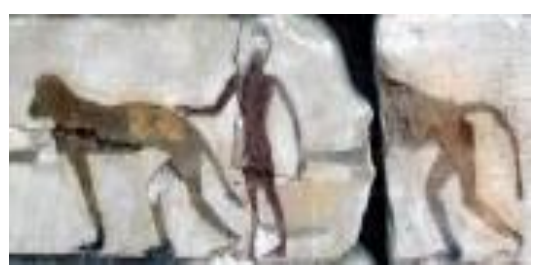

[FIGURE 11]:

Tomb of Nefermaat, Maidum. $4^{\text {th }}$ dyn.

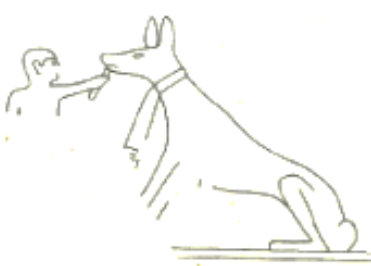

[FIGURE 14]:

Tomb of Pepiankh/ Meir. 


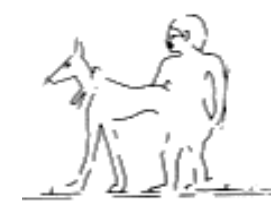

[FIGURE 15]:

rock-cut tomb of

Ankh-ma-ra/ Giza/ $5^{\text {th }}$ dyn.

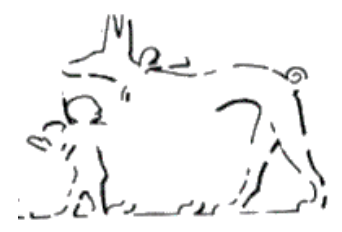

[FIGURE 16]:

Tomb of urana (wriri-ny)/ Sheikh Said. $5^{\text {th }}$ dyn.

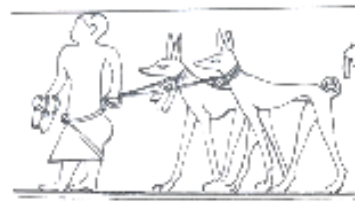

[FIGURE 17]:

Tomb of

Niankhnesut/

Saqqara. $6^{\text {th }}$ dyn.

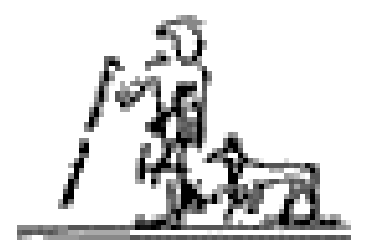

[FIGURE 18]:

dyn.

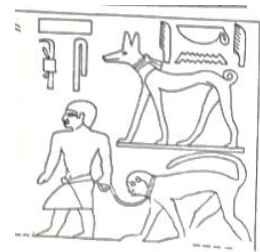

[FIGURE 19]:

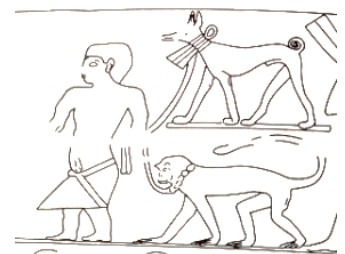

[FIGURE 20]:

Tomb of Neferirtenef/ Saqqara. $5^{\text {th }}$ dyn.

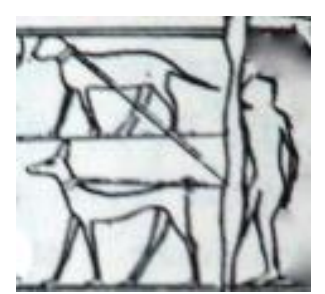

[FIGURE 22]:

Tomb of Nihetepptah /Giza. $5^{\text {th }}$ dyn.
Tomb of Hesi/ Saqqara. $6^{\text {th }}$ dyn.

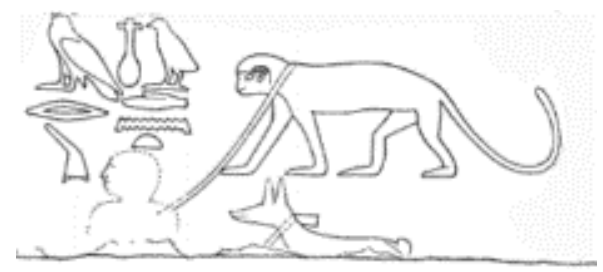

[FIGURE 21]:

Tomb of Seshemnefer-tjetti/ Giza. $5^{\text {th }}-6^{\text {th }}$ dyn.

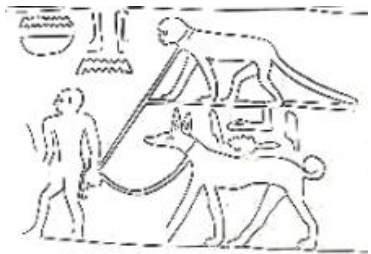

[FIGURE 21]:

Tomb of Nyankhnefertem/ Saqqara. $6^{\text {th }}$ dyn.

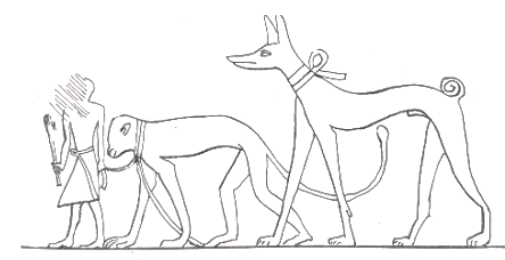

[FIGURE 22]:

Tomb of Ty/ Saqqara. $6^{\text {th }}$ dyn.

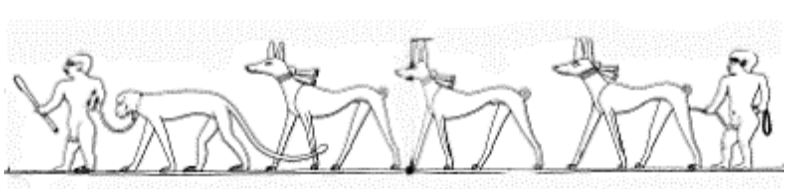

[FIGURE 23]:

Tomb of Mereruka/ Saqqara/ $6^{\text {th }}$ Dyn.

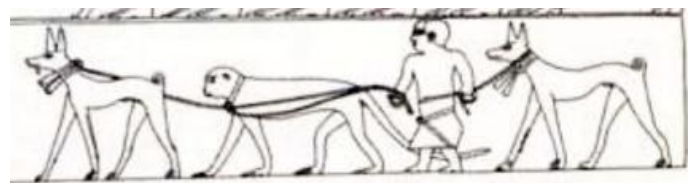

[FIGURE 24]:

Tomb of Kagemni/ Saqqara. $6^{\text {th }}$ dyn.

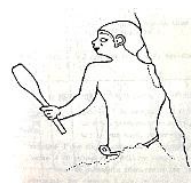

[FIGURE 25]:

Tomb of ITi sn/Giza.

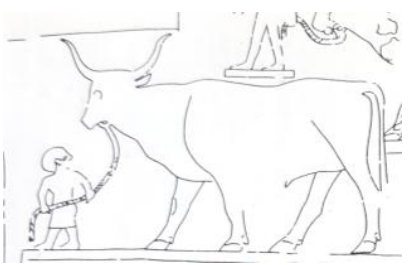

[FIGURE 26]:

Tomb of Kai-khent/ El-Hammamiya. $5^{\text {th }}$ dyn.

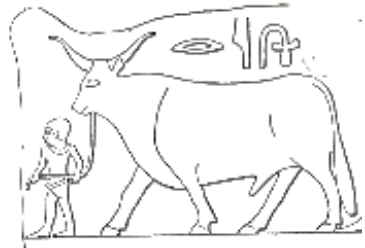

[FIGURE 27]:

Tomb of Ireru/ Giza. $5^{\text {th }}-6^{\text {th }}$ dyn.

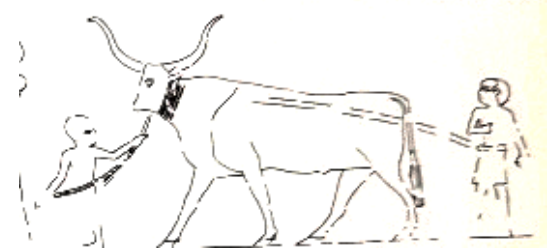

[FIGURE 28]:

Tomb of Inti/ Deshasha. $5^{\text {th }}$ dyn. 
Ola El-Aboudy: Representation Modes of Dwarf Animal - Keeper

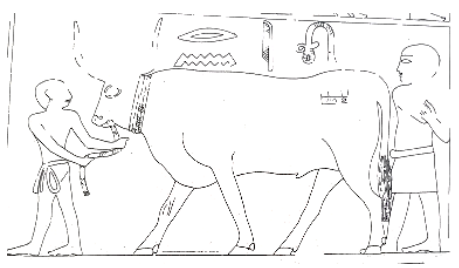

[FIGURE 29]:

Tomb of Inti/ Deshasha. $5^{\text {th }}$ dyn.

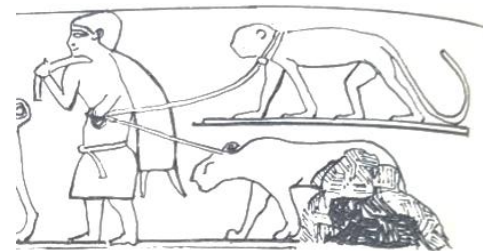

[FIGURE 31]:

Tomb of Niankhnesut/ Saqqara. $6^{\text {th }}$ dyn.

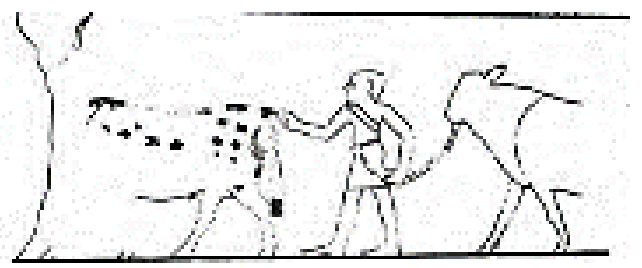

[FIGURE 30]:

Tomb of Zau/ Dier el Gebrawy.

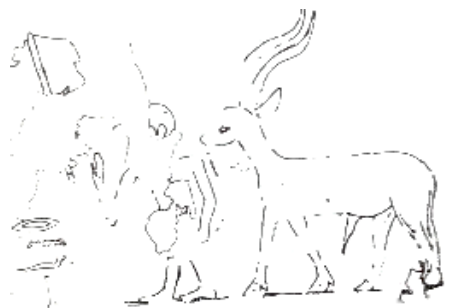

[FIGURE 32]:

Tomb of Mrw/Naga ed-Der. First Intermediate Period 